\title{
Recommendations for Co-existence of Coral Reef Conservation and Tourism at Pigeon Island National Park
}

\author{
N. Perera ${ }^{1 *}$ and S.W. Kotagama ${ }^{2}$ \\ ${ }^{1}$ Department of Zoology, Faculty of Natural Sciences, University of Colombo, Sri Lanka \\ ${ }^{2}$ Ministry of Sustainable Development and Wildlife, Government of Sri Lanka
}

Date Received: 19-11-2015

Date Accepted: 15-03-2016

\begin{abstract}
Pigeon Islands National Park (PINP) is one of the three Marine National Parks in Sri Lanka with coral reefs being the major habitat protected. A study was undertaken at PINP with the objective of understanding the challenges encountered and opportunities available for managing the park addressing both coral reef conservation and increasing tourism potential. Field visits, formal and informal group discussions, expert opinions, web based information and literature surveys were the methodology utilized.

Despise the impose of an entrance fee in May 2011, 146,375 tourists visited the 471 ha park within 40 month period. PINP earned LKR 37,000 ha ${ }^{-1}$ in 2013 indicating that one hectare of coral reefs can earn more revenue than larger terrestrial parks with charismatic species such as elephants. Foreign tourist arrivals had increased from $11.9 \%$ in 2011 to $25.13 \%$ by 2014 . Visitor reviews indicates that their experience was either excellent (46\%) or very good (30\%) due to abundance of marine life, while $12 \%$ had either a poor or a terrible visitor experience at the site owing to overcrowding, reef damage and high price.

With only $21 \%$ of live coral cover in 2013, it is evident that the reef is being degraded, indicating that a Protected Area which emphasizes on collecting user-fee revenues can lose sight of its primary conservation objectives and is not undertaking sustainable tourism. Park management effectiveness is not at desirable level (43\%), mainly due to non-implementation of a scientifically based management plan. A continuous monitoring programme to check the health of the reef is need, while the introduction of a multi-tiered user fee structures can enhance the economic reruns. Incorporating PINP into wider Seascape/landscape management through utilizing Special Area Management approach with relevant stakeholder participation needed to be promoted.

Keywords: Coral Reefs, Pigeon Island National Park, Management Effectiveness, Sustainable Tourism, Stakeholders
\end{abstract}

\section{Introduction}

*Correspondence: nmpperera@yahoo.com

Tel: +94779964451

ISSN 2235-9370 Print/ISSN 2235-9362 Online () University of Sri Jayewardenepura 
Pigeon Island National Park (PINP) is located $1 \mathrm{~km}$ off shore of the Nilaveli beach, in the Trincomalee District, Sri Lanka ( $8^{0} 45^{\prime} 0^{\prime \prime} \mathrm{N}$ and $81^{\circ}$ 9'0" E to $8^{0} 36^{\prime} 0^{\prime \prime} \mathrm{N}$ and $\left.81^{\circ} 14^{\prime} 0^{\prime \prime} \mathrm{E}\right)$. In 1974 , 4.6 ha area consisting of the two islands were declared as a sanctuary under Fauna and Flora Protection Ordinance (FFPO) for the purpose of protecting the nationally endangered wild rock pigeons (Columba livia), that colonize the rocky cliffs in large numbers. Realizing the importance of protecting the adjoining healthy reef system, the islands together with the surrounding sea area within a one-mile radius was upgraded in to a National Park in 2003 (IUCN SL/CEA, 2006; IUCN, 2002). The park boundaries is measured at $1,000 \mathrm{~m}$ radius from the central point between the two islands and extend to 471.4 ha, while part of PINPs buffer zone lies within the Nilaveli beach, which is a popular tourist destination (Figure 1).
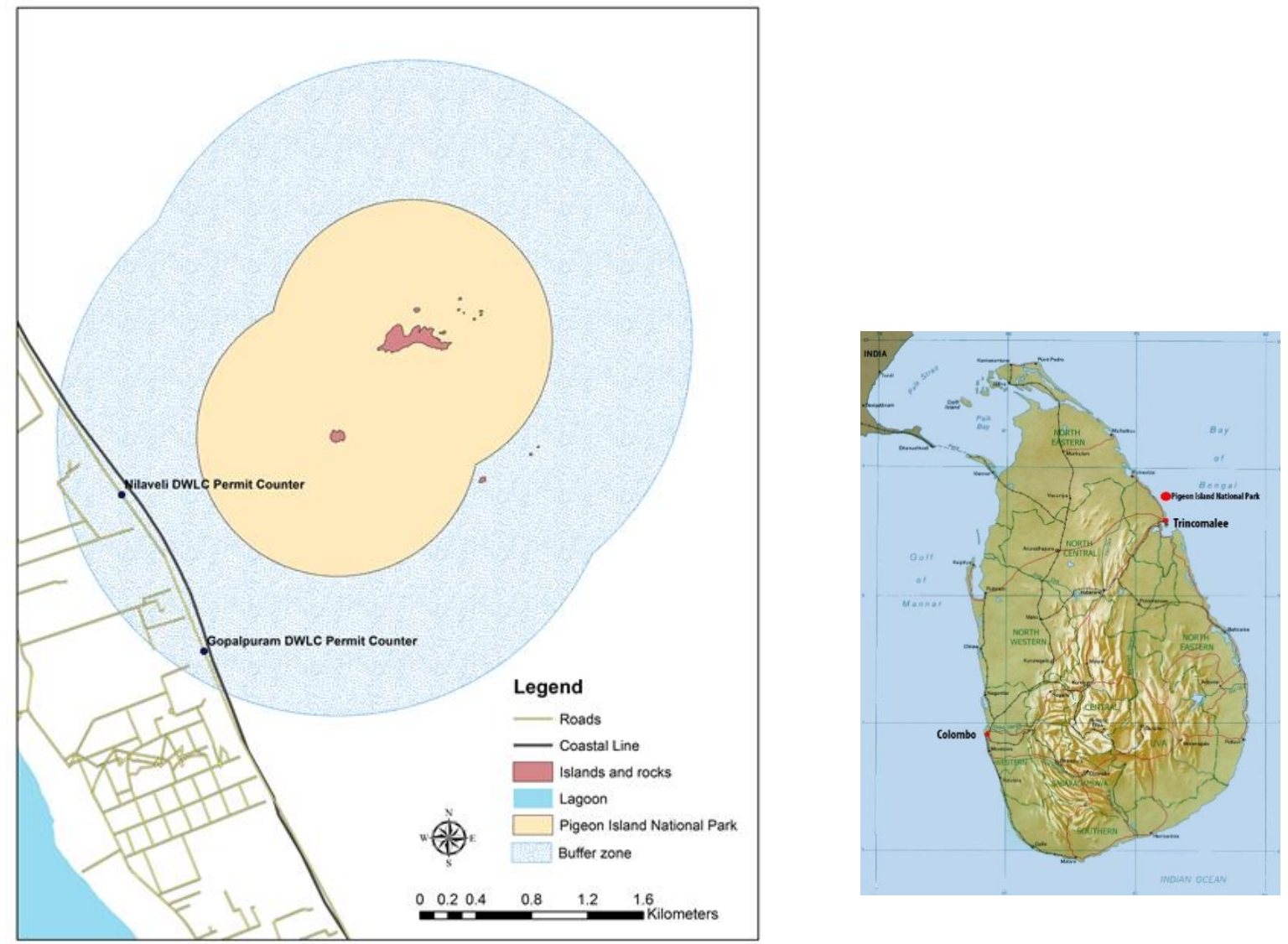

Figure 1: Location of the Pigeon Island national park.

(Prepared based on a map obtained from DWLC)

PINP is one of out of the three Marine National parks declared so far, the other two being the Hikkaduwa and the Adams Bridge. Available literature reveals that large scale destruction of coral reefs PINP occurred during the 1970s due to invasion of Acanthaster planci (Crown of Thorn Starfish - COTS), but have since recovered, with branching and tabulate Acropra spp being the dominant corals (De Bruin, 1972; Rajasuriya et al, 2005). To date, over 100 species of corals, and 222 species of reef fish have been identified, while three species of globally endangered marine turtles (Eretmochelys imbricata, Chelonia mydas and Lepidochelys olivacea) are also recorded. The Chetodon spp. are found in large numbers indicating that the reefs are not threatened by the 
aquarium trade. These reefs were not affected by the 1998 coral bleaching event or damaged by the December 2004 Tsunami, yet had suffered from reef walking, unregulated souvenir collection and the accumulation of solid waste (Rajasuriya, 2005; IUCN SL/CEA, 2006; Green Tech, 2009).

Globally, coral reef associated tourism plays a major role in revenue earning and is estimated to provide around US \$ 9.6 billion per year. Reefs not only support niche sub-market in scuba diving and snorkeling excursions, they also add value to the tourism product through associated images of exoticism and natural beauty. In this context, it is no surprise that in many developing nations with reef resources, tourism is an alternative industry to develop. Recreation can also pose distinct but potentially manageable threats to coral reefs including physical impacts from the use by snorkelers and divers. Once coral reefs are damaged, they are less able to support the many creatures that inhabit them and also loses value as a tourist destination. Yet by comparison to many other commercial uses of coral reefs, such as fisheries and mining, the direct impact of tourism is low, and therefore well planned tourism is likely to offer the most sustainable and profitable use of reef resources (Jobbins, 2006; Cesar et al., 2003).

Only recently tourism has become a popular mechanism to generate revenues and in this regard, user fees are the most popular instrument utilized. Examples of user fee types include admission to parks, fees charged to divers, special fees for accommodations, trophy and hunting fees or even special fees for rescue services (Hawkins, 1998). In the Sri Lankan context, out of the five existing categories of protected areas that falls under the purview of Department of Wildlife Conservation (DWC), presently tourism is actively promoted as a source of revenue generator only within National Parks (NP). As stipulated in FFPO 1937 and its subsequent amendments, in a NP the public can view and study wildlife by obtaining a permit paying a prescribed fee from an authorized person of the DWC. Application of an entrance fee to enter into PINP took place only in May 2011. With the ending of the armed conflict in May 2009, the roads and access were opened to the Eastern province leading a boom in the tourism industry in the region (DSD Kuchchaveli, 2014; EML Consultants, 2010; USAID, 2009).

In the above context, the present study was undertaken with the objective of obtaining a better understanding of the opportunities available and answers to challenges encountered in the future coexistence of coral reef conservation and tourism at PINP, and to deliver a set of recommendations for better management of the coral reef and other biological resources of the area for the sustainability of the tourism industry associated with it. The methodology of the study was designed to find answers to following aspects:

1. Visitor statistics and revenue generation through tourism

2. Understanding the factors contributing to visitor satisfaction and dissatisfaction

3. Present status of the coral reefs within PINP and whether the park management status is adequate to address the existing challenges

\section{Materials and Methods}

Information for the study was collected through field visits, formal and informal group discussions, expert opinions and literature surveys. Semi-structured interviews were used to obtain key stakeholder (wildlife officials, hoteliers, boat and dive tour operators) perceptions and experience in coral reef management and conservation issues. The study was built upon the 
information available on three recent reports produced under donor funded projects; GreenTech, 2009; and EML Consultants, 2013 and 2010. The best available secondary literature on the MPA was gathered through web-based search as well as visiting the government and non-governmental institutions involved in coral reef conservation activities. In order to understand the perceptions of tourists with regard to their experience at PINP, online web-based information available at Trip Advisor was utilised. This is acceptable as the importance of the online social travel networks for tourism businesses is gaining new attention in the academic literature (Xiang, 2010; Ban and Ramsaran-Fowdar, 2013). The management effectiveness the PINP was calculated utilizing the Score Card Method developed by the World Bank-WWF Alliance (Staub and Hatziolos, 2004).

\section{Results}

\subsection{Visitor statistics and revenue generation}

Preliminary study visit to PINP in October 2010 revealed that tourist were entering the National Park without obtaining a permit to view wildlife, as stipulated by FFPO. When visitors were questioned on site as well as off-site, it was evident that they were not aware of the protected status of the park or that they were actually doing an activity which is prohibited by the law. The log book kept by the navy indicated that considerable number of people visited the island, especially during the holidays and weekends. For example, 2,045 individuals had visited the island in the Month of September 2010. PINP was re-opened to the public and the issue of a permit was implemented by the DWC from $28^{\text {th }}$ May 2011. As illustrated by Figure 2, within a 40 month period, a total of 146,375 tourists had visited the park and the largest visitor number was recorded in August 2014, with 14,368 individuals paying a visit to the tiny island.

Annually there are two peak visitor seasons, which seems to be coincide with school holidays and international tourist arrival to the country. In April, the park is mainly visited by locals, while in August both locals and foreigners visit the area. Higher foreign tourist turnover is found in July-September period and the percentage of foreign tourist had increase from $11.9 \%$ in 2011 to $25.13 \%$ in 2014 . With the onset of North-east monsoons in mid-October, the number of visitors drops considerably and therefore in December, tourist numbers are low.

Parallel to visitor numbers, the revenue generated by DWLC through the issue of permits had also increased and for the year 2013, the park earned LKR 17,510,460.00 (US \$ 134, 695.85) being the NP, that earned the highest revenue per ha of area protected (LKR. 37,000 ha ${ }^{-1}$ ). This is a considerable achievement compared to much larger Category 1 Parks ${ }^{\dagger}$ such as Yala, and Wilpattu (Figure 3). For the year 2013 of the 18 NPs that were open to visitors, PINP earned the number fifth and seventh positions in visitor preference and revenue generation. During that year nearly three percent of the revenue generated was from the PINP indicating that healthy coral reefs are preferred by tourist much as larger wild charismatic animals such as Elephants and Leopards.

\footnotetext{
${ }^{+}$As per the regulations under Section 71 of FFPO (No. 1612/37, 31st July 2009), the entry fee paid by tourists to enter Category 1 National Parks are higher (local adult Rs. 60 and Foreign adult US\$ 15 or equivalent to Sri Lankan rupees) than for Category II National Parks (local adult Rs. 40 and Foreign adult US\$ 10 or equivalent to Sri Lankan rupees) and PINP is considered as a Category II National Park. Charges specified for vehicles, services and VAT are the same for the two categories
} 


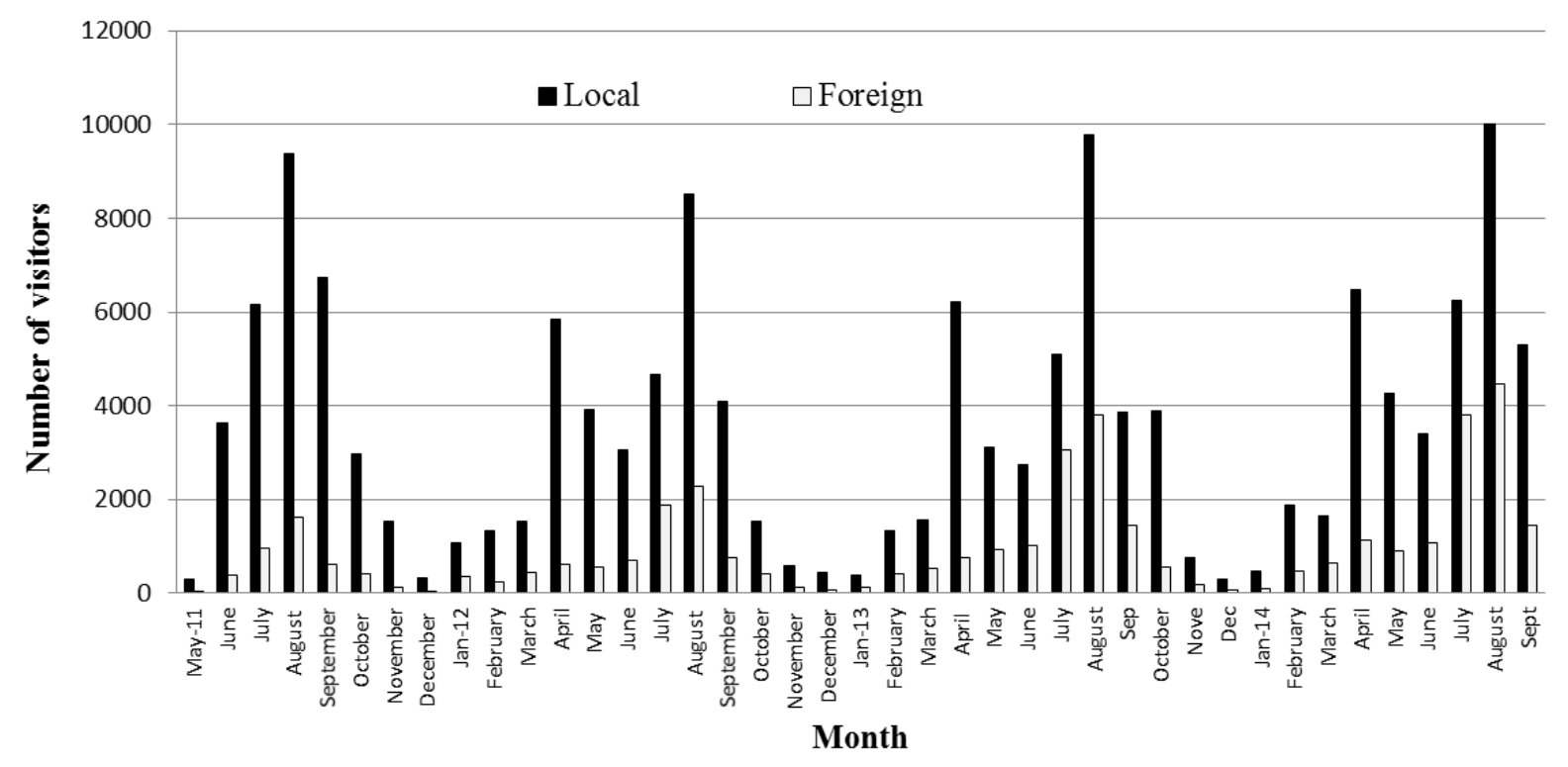

Figure 2: Visitor arrival at PINP from May 2011 to September 2014.

(Source: DWC).

The issue of a permit to the tourists to observe wildlife within PINP (as per Gazette Extraordinary No. 1612/37, 31st July 2009) is complex and promotes "group tourism" rather than providing individual options. This permit includes different categories of monetary allocations and there is vast difference in the final payment of a local and a foreign visitor (Table 1), indicating that a larger proportion of income generated is from foreign tourists.

Table 1: Comparison of different financial allocations included with in a permit issued by the DWLC to local and foreign visitors at PINP (in Sri Lankan Rupees).

\begin{tabular}{lll}
\hline Category of Allocation & Local & Foreign \\
\hline Park Fees For entry (tourist) & 40 & 1,280 \\
Local adult (boat driver) & - & 40 \\
Service charges & 300 & 1024 \\
Charges for parking the vehicle (boat) & 125 & 125 \\
12\% Vat & 55.8 & 296.28 \\
Total for 1 individual & 520.80 & $2,765.28$ \\
Total for 8 individuals (including the boat driver & 834.40 & $11,366.88$ \\
for foreign tourists) & & \\
\hline
\end{tabular}

Source: Notice board of PINP ticketing office.

As per legislation, this visitor permit can be issued to a party of person consisting of a maximum of 10 persons (including the driver) and in the case of PINP this number is reduced to eight as it is the maximum carrying capacity of most boats entering the park. This fee system is 
displayed at the ticketing counters and personal observations indicate that it confused especially the foreign tourists. Discussions with officials at DWC Headquarters revealed that a new gazette is about to be issued simplifying the present payment system and that individual tickets will be available thereafter.

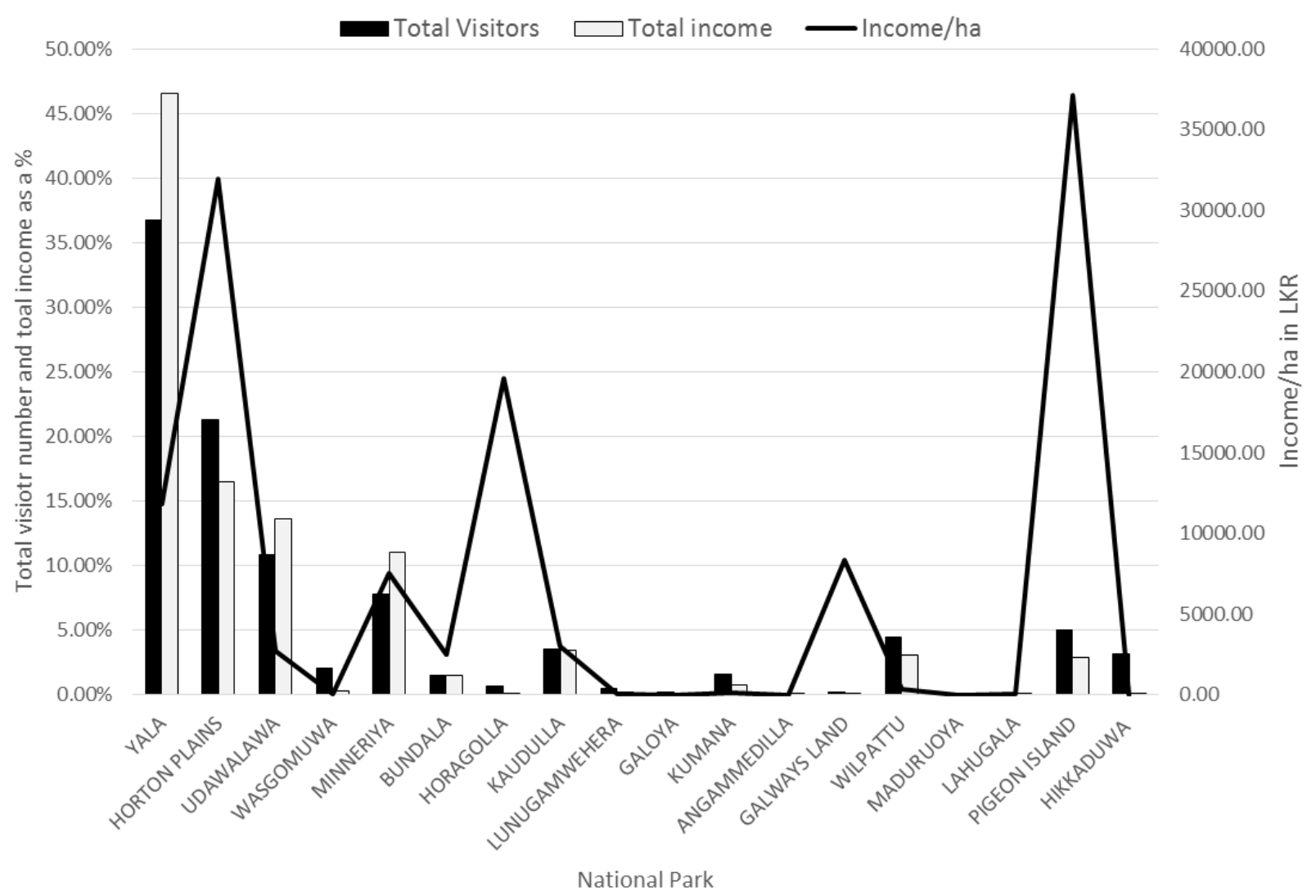

Figure 3: Comparison of visitor numbers, revenue earned and income/ha in National Parks for the year 2013.

\subsection{Boat operators and their concerns}

Presently 50 boats bring in tourists to the PINP, and out of this 33 belongs to the Nilaveli Tourist Boat and Service Co-operative Society Ltd (NTBSCS), which is registered in the Provincial Economic Ministry since April 2014. Six boats are operated by the hotels located within the Nilaveli beach stretch including Nilaveli Beach Hotel, Sea view, Pigeon Island Beach Resort, Pigeon island view and the Jungle Beach. Other boats are operated by the dive centers (e.g. Poseidon, Aqua Diving Center etc.), and about five boats are entering the park from other parts of Trincomalee (e.g. Boats belonging to Hotel Chaaya Blue, which is located about $10 \mathrm{~km}$ away from the PINP). Other than that Sri Lanka Navy utilises boats to bring in their staff members to the island, who are stationed there for security purposes. 
The boats of the NTBSCS are operated from two points within the Nilaveli beach, which is presently not a continuous beach stretch due to the installation of a navy radar system. 15 boats are operated near to Nilaveli Beach Hotel, while 18 enter the park from Gopalapuram. When considering the ethnic composition of the boat operators of these two locations, there is a considerable variation to be seen, with in Gopalapuram the majority being Tamils, while at Nilaveli beach point the majority are Muslims (Figure 4). An ethnicity difference was a barrier that was overcome when forming NTBSCS, which took few years' continuous deliberations.

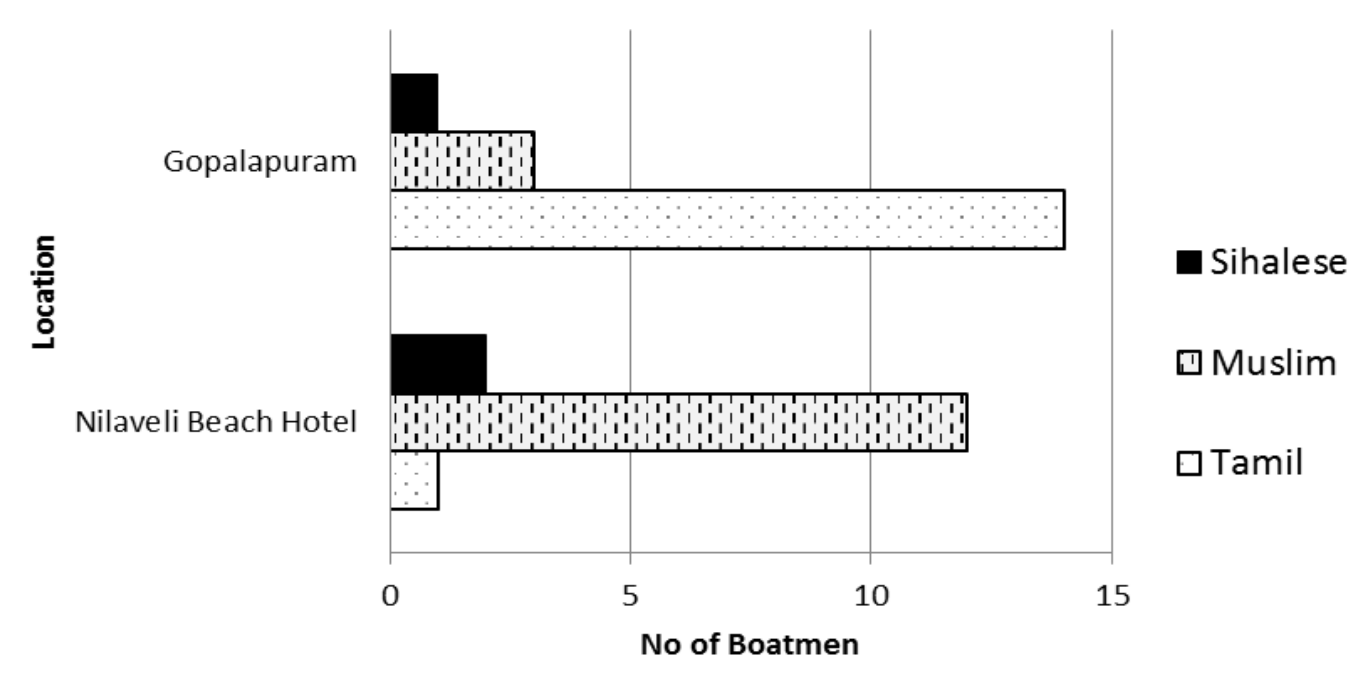

Figure 4: Ethnic composition of the boat operators of NTBSCS.

Of the 33 NTBSCS boats, nine are driven by the owners, while the rest is operated by hired drivers (mainly fisherman from the area) for a daily payment (LKR. 500 for one trip and LKR 800 for two trips). From April 2014, the society charge LKR 2,000 from tourists for a trip to PINP and the boat can accommodate a maximum of seven tourists. Although the distance to the park slightly differs from the two boat launching points, the charge is the same. NTBSCS is still not issuing a receipt for the boat service and the amount charged is too not displayed. If possible they try to overcharge the visitors.

As illustrated in Figure 5, the monthly revenue earned by the operators fluctuates and they face financial hardships, from November to March with limited turns to operate due to rough sea conditions. For example, in January 2014, for 14 days no boats were operated, while for the whole month only 120 boat terns were reported. The highest financial gains are from August. For example in 2013, 2,542 boat terns were reported, and if assuming that 40 boats were in operation during that month, they earn more than LKR. 127,100 per boat during that period. These operators also rent snorkeling gears to tourists, charging LKR 300-600 per set. Additionally they also offer whale watching and deep sea fishing tours and thereby diversify their livelihoods.

Lack of parking space at PINP is also an issue faced by the boat operators as well as the visitors. Presently there is space to park 15 boats and during the peak season these slots are mainly occupied by boats belonging to hotels and diving centers, who bring in divers and snorkelers that spend more than two hours in the park. Therefore, the NTBSCS operators have to anchor outside 
the park limits or go back to the point of origin. They have turn this opportunity brings more tourists during the peak periods and this some time lead to arguments between the visitors and boat operators.

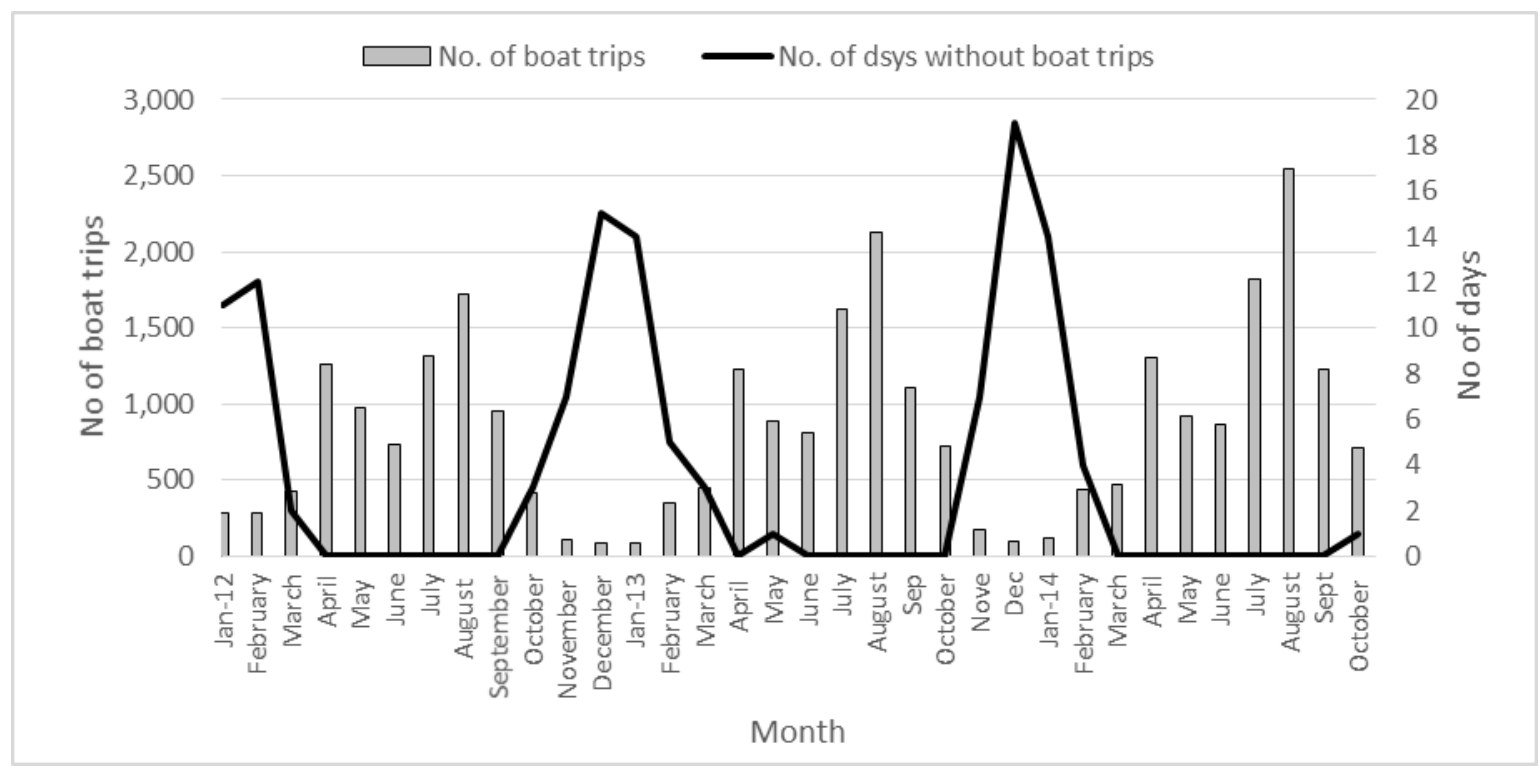

Figure 5: Boat turns and no of days without boats entering PINP.

Source: DWC.

\subsection{Dive tour establishments}

Another stakeholder who directly depends on PINP is the dive tour establishments. The diving season in Nilaveli starts in April and ends in September or mid-October. There are eight diving centers within the vicinity of PINP. This diving center not only offers diving expeditions, but also the opportunity to obtain PADI Diving license. As per the information gathered from discussion with dive tour operators, around the sea coast of Trincomalee there are around 12 diving sites. The park is not a preferred diving site due to two reasons; entrance fee and the shallowness of the area. Yet the park is used for training PADI divers as well as for snorkeling and many dive centers utilized sea areas just adjoining the park boundary for diving.

\subsection{Visitor perceptions}

The visitor reviews $(n=150)$ downloaded from Trip Advisor $\left(11^{\text {th }}\right.$ October 2014$)$ were from tourist that have visited the PINP from July 2012 to October 2014, with majority visiting the island in 2014. The contributors belong to 34 countries, with $50 \%$ being from Europe (Figure 6 a and b).

The reviews indicates that the main objective of visiting PINP is for snorkeling, while personal observations indicated that bathing is preferred by most local tourists. The overall visitor experience for PINP was "very good" with 76\% indicating that their experience was either excellent $(46 \%)$ or very good $(30 \%)$. Abundance of marine life and swimming with harmless reef sharks were sighted as reasons for the positive experience (Figure 7 and Table 2). 

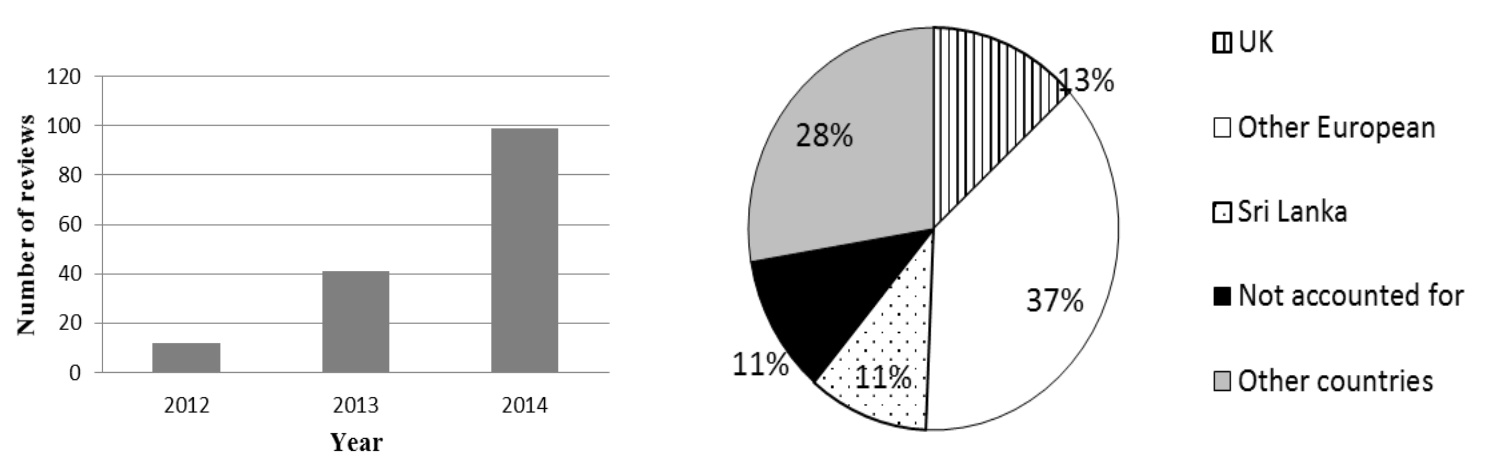

Figure 6: Analysis of trip advisor reviews by the (a) year and (b) country.

Table 2: Five most positive and negative visitor comments and suggestions to overcome the negative issues.

\begin{tabular}{|c|c|c|c|c|}
\hline Positive comments & $\%$ & $\begin{array}{l}\text { Negative } \\
\text { comments }\end{array}$ & $\%$ & Suggestions \\
\hline $\begin{array}{l}\text { Abundance of } \\
\text { colourful marine } \\
\text { life }\end{array}$ & 69.1 & Overcrowded & 27.0 & $\begin{array}{l}\text { Go before } 10.30 \text { a.m., limit the daily } \\
\text { visitor numbers }\end{array}$ \\
\hline $\begin{array}{l}\text { Swimming with } \\
\text { harmless reef sharks }\end{array}$ & 56.6 & Reef damage & 22.4 & $\begin{array}{l}\text { Awareness, guides to direct the } \\
\text { visitors; zonation; construct a } \\
\text { platform to reach deeper areas; not } \\
\text { letting the locals use the area as } \\
\text { bathing site }\end{array}$ \\
\hline Easy access to reefs & 15.8 & High price & 21.1 & Go as a group \\
\hline $\begin{array}{l}\text { Variety/good coral } \\
\text { cover }\end{array}$ & 14.5 & $\begin{array}{l}\text { Lack of visitor } \\
\text { facilities (water, } \\
\text { food, changing } \\
\text { rooms, toilets, and } \\
\text { shelter) }\end{array}$ & 19.8 & $\begin{array}{l}\text { Bring your own food and water; } \\
\text { come attired for swimming; apply } \\
\text { sun screen }\end{array}$ \\
\hline $\begin{array}{l}\text { Encounter with } \\
\text { turtles }\end{array}$ & 13.2 & $\begin{array}{l}\text { Lack/poor } \\
\text { management }\end{array}$ & 15.8 & $\begin{array}{l}\text { Re-think the park strategy; park } \\
\text { guards to be more proactive; utilize } \\
\text { the revenue generated for } \\
\text { conservation purposes }\end{array}$ \\
\hline
\end{tabular}

These ratings when compared to HNP (where only 9\% had an excellent trip, while $33 \%$ had a poor or terrible experience) is good, yet when comparing with terrestrial NPs such as Minneriya, Udawalawe and Horton Plains where less than 5\% of the visitors had poor or a terrible visitor experience, is not so encouraging. As indicated in Table 2 the main reason for poor visitor experience at PINP was overcrowding, which directly affect reef health. Only very few tourists venture inside the island to observe other attractions such as geological features or the nationally threatened wild rock pigeons. 


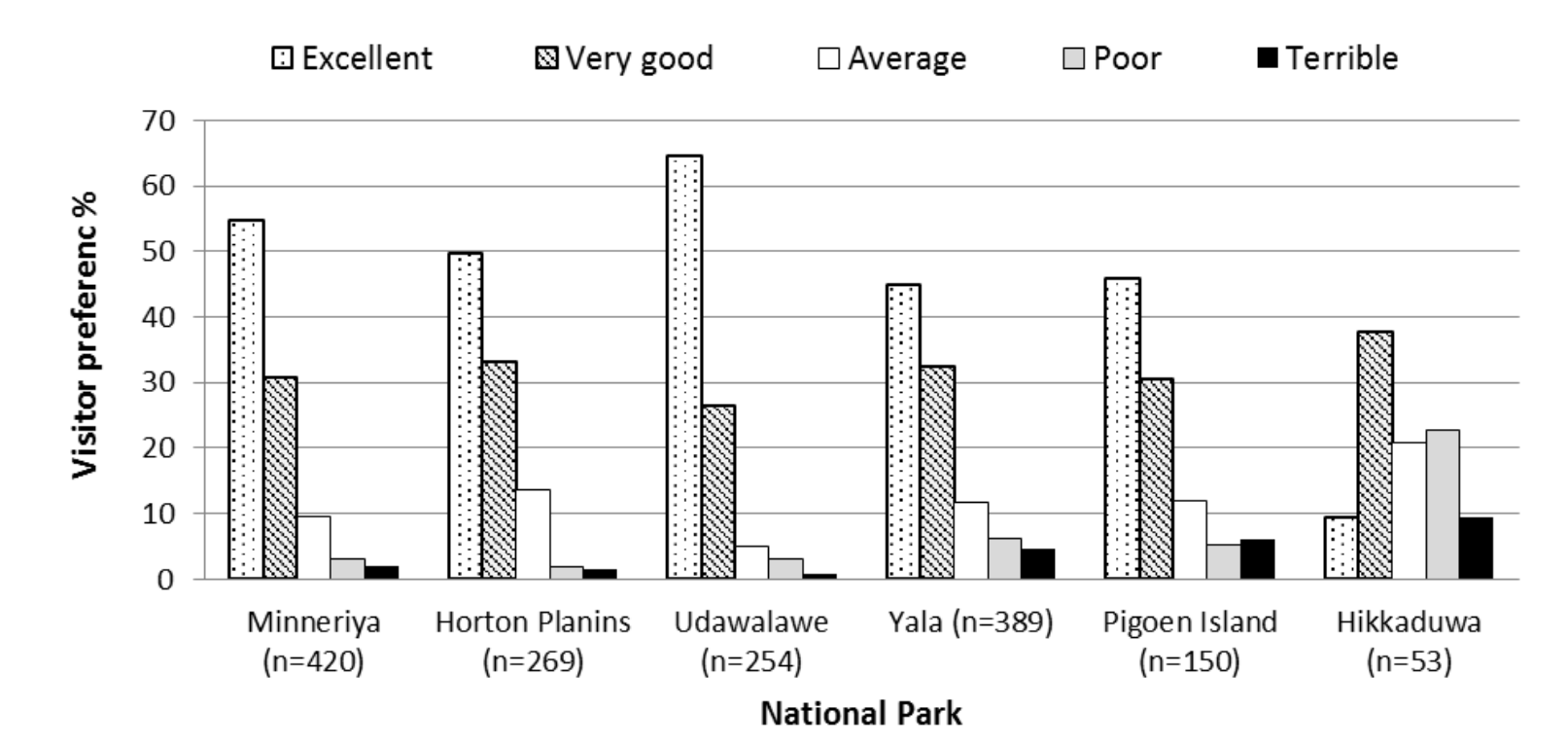

Figure 7: Visitor experience in six national parks of Sri Lanka. Source: http://www.tripadvisor.com (accessed on 11 ${ }^{\text {th }}$ October 2014).

\subsection{Present status of the coral reef}

Continuous in-depth scientific studies on the coral reefs ecosystem of PINP are lacking, and this is mainly due to inability to access the area during the civil conflicts that lasted for 30 years. Most of the information available is based on ad hoc surveys undertaken under various short-termed projects and initiatives. A research conducted in 1999 concluded that the live coral cover was $40 \%$ (Rajasuriya and Karunaratne, 2000). The live coral cover at PINP has reached its peak in 2005 (74 $\%$ ) as indicated in Rajasuriya, 2005, yet a study undertaken in 2013 reveals that only $21 \%$ of live coral cover is available (EML Consultants, 2013). This reduction can be attributed to increased threats and disparities in methodology utilised (especially the placement of transect including the location and the depth range) for each study.

As per expert opinion, threats such as visitor pressure, COTs infestation, accelerating growth of Halimeda sp., solid waste and coral bleaching are presently affecting the health of the coral reefs at PINP (Table 3). Further in 2010 there was severe bleaching of the coral reefs in the area, and they are now somewhat recovered (Rajasuriya, 2012). Pressures from destructive fishing including dynamiting, although reduced within the park limits are still practices in the vicinity and thereby influence the biological diversity, with serious impact on populations of mobile and mid-sized schooling species like snappers, sweetlips, trevally etc. Setting of fish traps in shallow reef areas is another threat recorded.

Although PINP is strictly a "no take zone", under the provision of the FFPO, yet prohibited fishing activities are still reported sporadically. As per information obtained by DWLC office at PINP reveals that during the last three year period (January 2012 - September 2014) DWLC had filed six cases against 10 fishermen who were involved in illegal fishery activities within the park boundaries. The offenders are prosecuted under two offences; entering the park without a permit 
and remaining and catching fish. In a case that was concluded in 2014 the offenders were fined LKR 15,000 per individual for the first offence and LKR 20,000 for the second. It is encouraging to note that the fishery permit issued under the Fisheries and Aquatic Resources Act (FARA) by the Fishery Inspector of Trincomalee north clearly stipulates that fishing is prohibited with in PINP limits. This stipulation has made it easy to prosecute the offenders. Recently a case was filed by a concerned tourist with regard to breaking of live coral corals within the NP and the verdict in this regard is still pending. This case highlights the fact that awareness in law amongst the general public can assist the concerned authorities to protect the natural resource base.

Table 3: Expert opinion on reasons for coral reef degradation at PINP.

\begin{tabular}{|c|c|c|c|}
\hline \multirow[t]{2}{*}{ Threat } & \multicolumn{2}{|c|}{ Ranking of threat ${ }^{*}$} & \multirow[t]{2}{*}{ Reasons for damage / general comments } \\
\hline & $\begin{array}{c}10 \text { years } \\
\text { ago }\end{array}$ & $\begin{array}{c}\text { Present } \\
\text { condition }\end{array}$ & \\
\hline $\begin{array}{l}\text { Threats related to } \\
\text { visitor pressure }\end{array}$ & 5 & 3 & $\begin{array}{l}\text { Collection of coral as souvenirs had reduced, yet visitor } \\
\text { pressure had increased with incidents of reef trampling } \\
\text { and boat damage to corals - this pressure is localized. }\end{array}$ \\
\hline $\begin{array}{l}\text { Crown of thorn } \\
\text { Starfish infestations }\end{array}$ & 4 & 3 & $\begin{array}{l}\text { Increase of COTS has been reported, which could } \\
\text { change with season. Ad hoc removal takes place. }\end{array}$ \\
\hline $\begin{array}{l}\text { Destructive fishing } \\
\text { activities including } \\
\text { blast fishing }\end{array}$ & 2 & 3 & $\begin{array}{l}\text { Applies to fish populations in the adjacent areas, to NP. } \\
\text { But serious impact on fish populations and to tourism in } \\
\text { the longer run }\end{array}$ \\
\hline $\begin{array}{l}\text { Accelerating growth } \\
\text { of calcareous algae } \\
\text { (Halimeda sp.) }\end{array}$ & 4 & 3 & $\begin{array}{l}\text { The bleaching event in May } 2010 \text { have led to a phase } \\
\text { shift occurred where other species benefitted, which } \\
\text { included calcareous algae. }\end{array}$ \\
\hline $\begin{array}{l}\text { Invasion by } \\
\text { corallimorpharians }\end{array}$ & 3 & 4 & $\begin{array}{l}\text { Corallimorpharians invaded parts of the reef in } 1999 \\
2000 \text { period. The areas carpeted by this species have not } \\
\text { increased significantly }\end{array}$ \\
\hline Cyclones & - & - & Not aware of damage by cyclones \\
\hline Tsunami & 4 & - & Low damage to PINP medium damage to coral island. \\
\hline Coral bleaching & 5 & 3 & $\begin{array}{l}\text { Severe bleaching in } 2010 \text {, but all corals did not die and } \\
\text { recovery is taking place. }\end{array}$ \\
\hline Sedimentation & 5 & 5 & There is not much sediment here \\
\hline Solid waste & 5 & 4 & $\begin{array}{l}\text { The degree of wastes from visitors has decreased due to } \\
\text { awareness, yet marine debris that drift with the current } \\
\text { get accumulated on the island edges. }\end{array}$ \\
\hline Coral diseases & 4 & 4 & $?$ \\
\hline Nutrient inputs & $?$ & 4 & Sewage pollution along the shoreline water in Nilaveli \\
\hline
\end{tabular}

* Percentage is based on the extent of damage compared to the whole area. Recovery is estimated from the time the threat is removed. Very high (1): Extensive damage (80\%-90\%) to almost the entire habitat and will take at least 10 years to recover; High (2): Significant damage (50\%-79\%) and damaged areas can recover within 7 years; Medium (3): Damage (20\%-49\%) is readily visible and damaged areas can recover in 4 years; Low (4): Damage (10\%-19\%) is very localized but readily visible, and recovery is within 2 years; Very low (5): Damage is $<9 \%$ and very localized and visible only by searching for damaged areas. 
Accelerated ad hoc development is also posing a threat to the survival of PINP. Nilaveli beach front is earmarked for tourism development. As indicated previously part of the buffer zone of PINP falls within the Nilaveli beach and stipulated by FFPO no development is permitted with in this area. As this situation is not helpful for the hotel industry development, the option of degazetting of PINP was considered in 2013. Due to pressure from environmental groups, it did not materialize, yet now the policy makers are looking at the option of shifting the boundaries of the Park to facilitate tourism development.

\subsection{Present park management status}

At present, the enforcement at PINP by its management authority (the DWC) is not up to desirable levels as indicated in visitor perceptions and by the value received for management effectives through the score card approach (42.98\% as indicated in Table 4). Lack of a management plan as well as staff that are well trained in managing MPAs are hindering DWC's ground level management efforts. DWC manage two ticketing/permit issue points within the Nliaveli beach stretch (i.e. the same locations where the boat operates: near to Nilaveli Beach Hotel and Gopalapuram) and also maintain two other small offices: one in the Nilaveli Beach and the other in the village. Presently there are only eight staff member including four volunteers (who are daily paid). As ticketing is done manually, at least four staff members are required in the two ticketing offices, especially during peak tourist season and as a result the number of staff on the island itself to manage the visitors are limited to one or two. Frequent transfer of staff is also a problem. A motorboat has been recently acquired through a GEF funded Small grant project, while Navy and Police assist in monitoring visitors.

Table 4: Management effectiveness of PINP - Score Card summary (as of October 2014).

\begin{tabular}{llll}
\hline & $\begin{array}{l}\text { Maximum } \\
\text { possible score }\end{array}$ & $\begin{array}{l}\text { Your } \\
\text { score }\end{array}$ & $\begin{array}{l}\text { Final score } \\
(\%)\end{array}$ \\
\hline A- Context - Where are we now & 26 & 14.5 & 55.76 \\
B- Planning - Where do we want to be & 14 & 04 & 28.57 \\
C- Inputs -What do we need & 14 & 07 & 35.71 \\
D- Process - How do we go about management & 25 & 8.5 & 50 \\
E- Outputs -What were the results & 33 & 15.75 & 34.0 \\
F- Outcomes- What did we achieve & 27 & 10 & 47.7 \\
& & & \\
Total Score & 139 & 59.75 & 42.98 \\
\hline
\end{tabular}

It is well known fact that at entrance points park managers have the most control over visitor numbers, distribution and behavior. Ideally as in other popular terrestrial NPs, when visitors arrive, they proceed immediately through a reception area where they can be met, have regulations explained, numbers counted, entrance fees collected and tours arranged with a tracker. Yet, as this is not practical at PINP, a visitor center that will ensure visitors have information about where to go, what to do and what not to do during the visit is required on land. 


\section{Discussion}

Tourism, like other economic development tools, is a two-edged sword, with the economic, learning and political benefits of tourism come potentially significant social and environmental costs, and these costs may be particularly deleterious in and near protected areas. With careful sensitive management attending to the notion of sustainability, these costs can be minimized (McCool, 2006). As tourism demand at PINP is increasing, there is the need to move towards greater industry self- regulation, training and accreditation to ensure more efficient management of tourism use at the park as well its surroundings.

If managed in isolation, coastal and marine protected areas are vulnerable to natural resource development and exploitation occurring outside these areas and therefore it is recommended widely that MPAs should be integrated into spatial development strategies for larger areas, under the umbrella of integrated coastal and ocean management (ICM). A good example in this regard is found from Belize barrier reef, the current 14 MPAs are treated as tools for achieving ICM (Cicin-Sain and Belfiore, 2005). With respect PINP, participating in Special management area (SAM) process of the Coast Conservation Department (CCD) is vital in this regard. The 2006 Coastal Zone Management Plan prepared by CCD identifies the Nilaveli beach and the Pigeon Island as a potential SAM site. Amendments to the Coast Conservation Act, No. 57 of 1981, in February 2011, provides legal provision to declare SAM sites through gazette notifications if it need to adopt a collaborative approach to planning resource management within the defined geographic area. Further the Minister in charge of CCD may make regulations prescribing the manner and mode in which, and the persons by whom, such SAM site should be administered, the persons entitled to have access to these areas and the activities which can be carried out within such areas.

GEF funded participatory coastal zone restoration and sustainable management in the Eastern Province of post-Tsunami Sri Lanka, which is being presently implemented by the Ministry of Fisheries and the Coast Conservation Department, promotes the restoration and sustainable use of ecosystems along the Eastern Coast of Sri Lanka damaged by the Indian Ocean tsunami through the SAM approach. This Project will strengthen the capacity of DWC to manage Pigeon Island National Park and enforce park rules. DWC will be supported in developing a management plan for Pigeon Island and its vicinity that meshes with the community co-management plan with the aim of establishing a sanctuary to demarcate a strict conservation area for the core reef with limited resource extraction beyond. Coordination between the national park management plan and the community co-management plan will be essential to ensure no conflicts arise.

The capacity to apply different types of fee system from different park users has not been explored at the PINP. This is not the case in elsewhere of the world. For example a survey conducted in Caribbean and Central America indicate that out of 74 MPAs throughout the region, 53 MPAs (70\%) use different types of fee system with charges being levied per dive, per day, per boat, and per tank. In some cases charges are not levied on individual divers but on operators as an annual fee or percentage of income. Thirty-four (64\%) of the MPAs charging scuba divers levy a fee on individual divers. This ranges between USD 1 and USD 50 although fees at the lower end of this scale are most usual (Green and Donnelly, 2003).

Further studies conducted in three major dive destinations in Philippines indicate that most divers would be willing to pay an entrance fee to maintain sanctuaries where fishing one of the 
major threats to coral reefs is prohibited. Moreover, the entrance fee may be used as a tool to regulate the number of visitors to minimize visitor damage. These revenues could be used to support coral reef conservation and possibly the creation of alternative employment opportunities for locals who would be barred from fishing, their traditional income generating activity (Arin and Karmer, 2002). However, at PINP, very limited portion of the revenue generated is used for conservation purposes at the site itself, while the larger portion of the money earned from permits is either sent to the Treasury of the Central Government and to the DWC headquarters.

\section{Conclusion and Recommendations}

The proposition that PINP management should lead to win-win outcomes for both conservation and tourism development satisfying the needs of all relevant stakeholders including conservationists, government officials, tourists, and tourism operators was the dominant paradigm addressed in this case study. The successful achievement of this dual mandate is more complex than in theory and therefore the park management options needed to be re-thought off. It is evident that the growth of tourism in the east coast has resulted in an increasing number of tourists visiting PINP, despise the impose of an entrance fee system. Analysis of data indicated that one hectare of healthy coral reef can earn more revenue than from a larger terrestrial parks that provide a home to charismatic species such as elephants and leopards with bigger home ranges.

The examining visitor perceptions indicated that swimming with a multitude of colourful fish, and the Black tip reef shark is the main attraction for snorkelers. It also reveals that the reef is being degraded at PINP and the park is over-crowded especially in April and again in AugustSeptember period, leading to visitor dissatisfaction as well as reef degradation. This indicates that although user fees can be useful for raising much-needed revenue, there are several dangers in this funding mechanism. One is the risk of over-commercialisation promoting mass tourism. A PA which emphasizes user-fee revenues can lose sight of its primary conservation objectives and overdevelop facilities designed to produce income rather than protect natural resources. Other risks include deploying scarce resources toward collecting fees rather than protecting resources, creating controversy and public opposition, a fact that is evident from the visitor reviews, where poor/nonpark management interventions as well as lack of visitor services have been highlighted. Further the degradation of reef ecosystem due to A. planci attacks as well as a continuous monitoring programme to check the health of the reef need to be addressed in a more systematic manner, with the involvement of stakeholders including universities, dive tour operators as well as boat operators. Given the seasonal nature of tourism industry incomes that mainly depend on weather patterns, the boat operators find it difficult to secure a dependable livelihood throughout the year. Providing them with alternative sources of income as well as proper guidance in conducting tourism will assist in both.

Park management must pay close attention to tourism impacts in the future. Failure to do this could result in a destructive feedback loop that would contribute to the degradation of the reef and, ultimately, PINP's diminished competitiveness in the tourism industry as a destination for viewing a healthy coral reef. As stated by one tourist "The national parks department really need to rethink their strategy here, otherwise there will be nothing left in five years and you can wave goodbye to the sharks and turtles". 
Following recommendations are provided for meeting the challenges for promoting both reef conservation and sustainable tourism at PINP.

- The boundary of PINP could be re-demarcated in a manner that will not have an impact on tourism developments in the Nilaveli beach, but it should captures more marine areas so that illegal activities such as blast fishing can be better managed.

- DWC to actively involve all relevant stakeholders in all stages of PA management planning, development and implementation. i.e. in reef monitoring removal of COTS, patrolling, financial resources.

- In depth studies are needed to be undertaken for better understanding on the importance of maintaining a healthy reef at PINP. Such studies include spillover effect, visitor carrying capacity, economic analysis (willingness to pay extra for preserving the reef and limiting the tourist numbers).

- Introducing concept such as "green-fin operators" to protect and conserve coral reefs by establishing and implementing environmental friendly guidelines for divers need to be looked into.

- The Nilaveli Tourist Boat and Service Co-operative Society Ltd (NTBSCS) need to be empowered with a professional outlook in handling visitors as well as managing the society. Due to seasonality of the industry, alternative livelihoods need to be introduced.

- Maintaining two ticketing issue offices by DWC is not practical in the long run and one central office complex together with visitor interpretation facilities needed to be established.

- Implementation of a variety of user fee structures can be applied to enhance the economic rerun from the park and thereby making it more attractive to government for keeping it protected.

- To channel tourist demand from the fragile coral reef ecosystem to more impact-resilient areas such as a theme park can be built in the surrounding beach front.

- PINP could be included within a much wider management system such as a Special Area Management Site.

\section{Acknowledgment}

The authors thank the Department of Wildlife conservation and especially its officials based at Pigeon Island National Park. Mr. Arjan Rajasuriya and Nishan Perera is acknowledged for providing feedback on coral reef status.

\section{References}

Arin, T., and Kramer, R., 2002. Divers' willingness to pay to visit marine sanctuaries: An exploratory study. Ocean \& Coastal Management 45:171-183.

Ban, J., and Ramsaran-Fowdar, R.R., 2013. Developing a model for online social travel networks in the tourism industry. Proceedings of 23rd International Business Research Conference 18-20 November, 2013, Marriott Hotel, Melbourne, Australia, ISBN: 978-1-922069-36-8.

Cicin-Sain, B., and Belfiore, S., 2005. Linking marine protected areas to integrated coastal and ocean management: A review of theory and practice. Ocean \& Coastal Management 48(1112): 847-868.

Cesar, H., Burke, L., and Pet-Soede, L., 2003. The economics of worldwide coral reef degradation. Cesar environmental Economic Consulting, Amsterdam. 
De Bruin, G., 1972. The crown of thorn starfish Acanthaster planci (Linne) in Ceylon. Bull. Fish, Res. Stin., Sri Lanka, 23(1 \& 2): 37-41.

DSD Kuchchaveli., 2014: Divisional resource profile of Kuchchaveli division, 2014.

EML Consultants (Pvt) Ltd., 2013. Consultancy services for establishing baseline inventories of flora and fauna in three identified coastal ecosystem in the Eastern province Part I - Pigeon Island national park and surrounding coastal ecosystems.

EML Consultants (Pvt) Ltd., 2010. An analysis of current and future economic value of coastal resources in the Eastern province in Sri Lanka. Study 14. North East Coastal Community Development Project.

Green, E., and Donnelly, R., 2003. Recreational scuba diving in Caribbean marine protected areas: Do The Users Pay? Ambio 32(2). Royal Swedish Academy of Sciences 2003. 140-144.

GreenTech Consultants., 2009. A review of coral reefs on the East coast of Sri Lanka: distribution, ecology, status and threats, final report, Pp 93, Annexure 04, August 2010, NEC/PO/TECS(III)/08/18,NECCDEP/GreenTech Consultants, ADB LOAN 2027 SRI (SF): North East Coastal Community Development Project (NECCDEP).

IUCN Sri Lanka and the Central Environmental Authority. 2006. National wetland directory of Sri Lanka, Colombo, Sri Lanka. 229-233.

IUCN Sri Lanka., 2002 Conservation of coral reefs around Pigeon Island, Trincomalee, Issue Paper, Prepared by IUCN Sri Lanka with technical inputs from NARA.

Jobbins, G., 2006. Tourism and coral reef conservation: can they co-exist? In Isabelle M.C. and John, D.R. (eds) Coral Reef Conservation. Conservation Biology Cambridge University Press. 13: 237-262.

McCool, S., 2006. Managing for visitor experiences in protected areas: promising opportunities and fundamental challenges Parks. The International Journal for Protected Area Managers. The Visitor Experience Challenges. 16(2): 3-9.

Rajasuriya, A., 2012. Provisional checklist of corals in Sri Lanka. In Weerakoon, D.K. and Wijesundara, S. (eds) The National Red List 2012 of Sri Lanka; Conservation status of the fauna and flora. Ministry of Environment, Colombo, Sri Lanka. 376-383.

Rajasuriya, A., Perera N., Fernando M., 2005. Status of coral reefs in Trincomalee, Sri Lanka. In Souter, D. and Lindèn, O. (eds). Coral reef degradation in the Indian Ocean: Status report 2005. CORDIO, Department of Biology and Environmental Science, University of Kalmar, Sweden. 97-103.

Rajasuriya, A., 2005. The status of coral reefs in Sri Lanka in the Aftermath of the 1998 coral bleaching event and the December 2004 Tsunami. In Souter, D. and Linden, O. (eds). Coral Reef Degradation in the Indian Ocean: Status Report 2005. 83-96.

Rajasuriya, A., and Karunaratne, C., 2000. Post-bleaching status of the coral reefs of Sri Lanka. Coral reef degradation in the Indian Ocean: Status report and project presentations 2000. 5463.

Staub, F., and Hatziolos, M., 2004. Score card to assess progress in achieving management effectiveness goals for marine protected areas. Prepared for the World Bank. Revised version July 2004.

USAID, 2009. Assessment of tourism in Eastern, Uva and North Central provinces of Sri Lanka. Prepared under USAID Contract Number 383-C-00-08-00500-00. Sri Lanka Connecting Regional Economies (USAID/CORE) Programme.

Xiang, Z., and Gretzel, U., 2010. Role of social media in online travel information search. Tourism Management, 31:179-188. 